\title{
SOME POPULATION ASPECTS OF COMMON TERN Sterna hirundo BREEDING IN ALGERIA AT A SMALL MEDITERRANEAN ISLAND (EAST COAST OF ALGERIA)
}

\author{
MOHAMED DHAYA EL-HAK KHEMIS $\varpi^{1}$, LAMIA BOUTABIA², KAMILIA FARHI ${ }^{3}$, ALI ELAFRI ${ }^{4}$, ASMA KAHLI ${ }^{5}$, \\ SALAH TELAILIA ${ }^{2}$ \\ ${ }^{1}$ Department of Biology, Faculty of Sciences, Badji Mokhtar University, Annaba, P.O. Box 12, 23000, Annaba, Algeria; e-mail: khemis.dhaya@yahoo.com \\ ${ }^{2}$ Laboratory of Agriculture and Ecosystem Functioning, Department of Agronomy Sciences, Faculty of Natural and Life Sciences, Chadli Bendjedid University, \\ El Tarf, P.O. Box 73, 36000, El Tarf, Algeria; e-mail: b_lamiadz94@yahoo.fr, s_azzidz@yahoo.fr \\ ${ }^{3}$ Laboratory of Promotion of Innovation in Agriculture in Arid Regions, Mohamed Khider University, Biskra, Algeria; e-mail: kamilia.farhi@gmail.com \\ ${ }^{4}$ Department of Biology Abbes Laghrour University, Khenchla 40000, Khenchla, Algeria; e-mail: alielafri@gmail.com \\ ${ }^{5}$ Department of Biology, Faculty of Natural and Life Sciences, Chadli Bendjedid University, El Tarf, P.O. Box 73, 36000, El Tarf, Algeria; e-mail: asmakahli@ \\ hotmail.com
}

$\bowtie$ Corresponding author

Received: 15 August 2019 / Accepted: 1 November 2019

Abstract

Khemis M.D.E., Boutabia L., Farhi K., Elafri A., Kahli A., Telailia S.: Some population aspects of Common Tern Sterna hirundo breeding in Algeria at a small mediterranean island (east coast of Algeria). Ekológia (Bratislava), Vol. 40, No. 1, p. 62-69, 2021.

\begin{abstract}
We present the first detailed study of population dynamics, breeding biology and egg measurement of Common Terns. During six years (from 2004 to 2009) of monitoring, from mid-May to mid-August, 74 Common Terns individual were recorded at Laouinet small island, El Tarf, northeast of Algeria, witha finite population growth rate that indicated an alarming population decline $(\boldsymbol{\lambda}=-0.62:$ Lambda). Sterna hirundo build its nests $(\mathrm{n}=$ 37 ) in the northeast at a mean distance of $7.58 \mathrm{~m}$ from the closest edge of rocks. The nests were closed and ovoid, constituted mainly of mussel shells Sandpit, stems and leaves. Incubation was performed by pairs of common tern and lasted $25.5 \pm 3.4$ days. We recorded a clutch size of 1 to 3 eggs with mean clutch size of $2.45 \pm 0.65(41.24 \pm 0.83 \times 30.46 \pm 0.62 \mathrm{~mm})$. The egg parameters (volume, mass, shape index) varied between the six years of the study. The egg volume (19.24 \pm 0.87$)$ depended more on egg width $(30.46 \pm 0.62)$, however the egg shape $(0.73 \pm 0.20)$ depended negatively on the egg length $(41.24 \pm 0.83)$ but not on the egg width. Our results also showed a stabilized hatching success and a best estimation of breeding success. The hatching success did not vary between years: $70.5 \%$ in $2004,68.75 \%$ in $2005,71.42 \%$ in $2006,71.42 \%$ in $2007,69.23 \%$ in 2008 and $69.23 \%$ in 2009 .
\end{abstract}

Key words: unique population, Sterna hirundo, egg parameters, little rocky, marine environment.

\section{Introduction}

Seabird's taxa were the precursor to invasion of marine habitats (Kildaw et al., 2005); they breed in large colonies (Belopol'skii, 1957; Pearson, 1968; Croxall, Prince, 1980; Hunt et al., 1981). Seabirds are an integral part of marine ecosystems. Because they are top predators and are connected closely to the marine environment, they are often used as indicators of marine ecosystem health, and can be very useful in monitoring marine environmental changes: as levels of pollution; changes in fish stocks or water productivity (Diamond, Devlin, 2003; Weimerskirch et al., 2003). Seabird's species are highly affected by the decline especially in the last few decades (Croxall et al., 2012). This makes their protection and conservation a priority need, for those species and the management of their marine habitats (Croxall et al., 2012; Šúr et al., 2013; Page, 2014). In the Mediterranean Sea, marine locations - mainly small Islands - are a hotspot for Mediterranean biodiversity, they shelter a high number of species, and represent a real stake for the protection of the Medi- terranean biodiversity (Blondel, Aronson, 1999; Monbailliu, 2013). Also, these closed localities representa nesting place for numerous emblematic birds like shearwaters, Eleonora's falcons or ospreys; they shelter, for example, the largest population of Scopoli's Shearwater Calonectris diomedea on Zembra Island, Tunisia (Defos du Rau et al., 2012), the island of Tavolara in Sardinia for the Yelkouan Sheawater (Baccetti et al., 2009), and the island from Filfla to Malta for the Storm Petrel (LoValvo, Massa, 2000). Brief, small islands can be the barometers of the world, a double recognition that implies to protect them. On these habitats, sea birds spend a major part of their offshore life and find refuge on islands to insure their breeding requirements, far away from human disturbances and predation. Therefore, breeding parameters (reproductive success) are one of the most important ecological requirements of determining population dynamics in seabird, and they contribute considerably to the abandonment or the occupancy of such small islands (Martínez-Abraín, 2003). Lies between 1 and $2 \mathrm{~km}$ from the Algerian coast, small islands and little rocks have attracted little field work by ornithologists

(c) The Author(s) 2021. This is an open access article distributed under the terms of the CC BY-NC-ND license.

https://content.sciendo.com/view/journals/eko/eko-overview.xml 
and land managers. Only three significant efforts have been conducted regarding this topic: at Srigina and Saint Piastre, the breeding biology of Cory's Shearwater (Calonectris diomedea) (Telailia et al., 2014), at the Rachgoun Island, the breeding biology of Cory's shearwater (Taibi et al., 2014), and at a small Rocky Islet offshore of the "Plage des Goélands" near El Kala, the breeding of Common Terns (Michelot, Laurent, 1992, 1993; Baaloudj et al., 2018).

The Common Tern (Sterna hirundo) is a migratory (del Hoyo et al., 1996; Snow, Perrins, 1998) colonial seabird, widespread over its large breeding range (Nisbet et al., 2017; Becker, Ludwigs, 2004; Yésou et al., 2005); with a global population estimated between $1,600,000$ and 4,600,000 individuals (Wetlands International, 2006) however, the decrease in these figures was reported by several authors in the world (Scarton, 2010; Erwin et al., 2011; Morris et al., 2012; Szostek, Becker, 2012; Nisbet et al., 2013) despite its current status (Least Concern) (UICN, 2018). However, the Common Tern seems to be well studied by many authors (Scarton, 2010; Erwin et al., 2011; Morris et al., 2012; Szostek, Becker, 2012; Nisbet et al., 2013, 2017; Becker, Ludwigs, 2004; Yésou et al., 2005; Chokri et al., 2010) through its range, except in North Africa where only two studies were conducted in (a) Algeria (Baaloudj et al., 2018) and in (b) Tunisia (Chokri et al., 2010).

In order to develop a spirit of marine and coastal environmental protection, mainly regarding several small and ignored islets, in this research paper, we highlight the ecological value of a single breeding small island for the unique population of Common Terns in Algeria (Laouinet, east coast of Algeria), through a regular surveys of six breeding seasons, and by monitoring several aspects of the species reproduction patterns such as: (1) population dynamics, (2) nests characteristics, (3) clutch and eggs measurements, (4) incubation and hatching, and (5) relationship between the clutch size and egg measurement to latitude.

\section{Material and methods}

This work was carried out for six consecutive breeding seasons (2004-2009) from mid of May to mid of August by (Salah Telailia), we performed a phenological monitoring and counting of Common Tern individuals, and pairs, twice per week in the little rocky of Laouinet north east of Algeria, using binoculars $(90 * 90)$ and a telescope $(60 * 80)$ to locate nests. Once the nest is located, we recorded the date of its discovery, its geo location using a GPS (Garmin) and its distance from the edge on rocks, the nest dimensions (internal diameter and external diameter). We also measured the clutch size (number of eggs per nest), the eggs' weight using an electronic scale ( $0.01 \mathrm{~g}$ of accuracy) and their length (A) and width (B) using an electronic vernier caliper. We estimated, eggs volume with Hoyet's formula (1979) ( $\mathrm{V}=0.51 \times \mathrm{A} \times \mathrm{B} 2)$, fresh mass (fresh mass $=0.542 \times$ A x B2), and Egg shape with Panda formula (1996): Egg shape $=(\text { egg } B / \text { egg A })^{\star} 100$. The two visits per week allowed us to estimate the incubation period (Del Hoyto et al., 1994); also to monitor the hatching success (the ratio between the number of eggs laid and the number of hatched eggs).

\section{Study area}

The little rocky of Laouinet is situated in the central Mediterranean basin, northeast of Algeria exactly in the east of El Kala golf $\left(36^{\circ} 54^{\prime} 24.85^{\prime \prime} \mathrm{N}, 8^{\circ} 29^{\prime} 16.95^{\prime} \mathrm{E}\right)$, with a surface area of $50 \mathrm{~m}^{2}$.
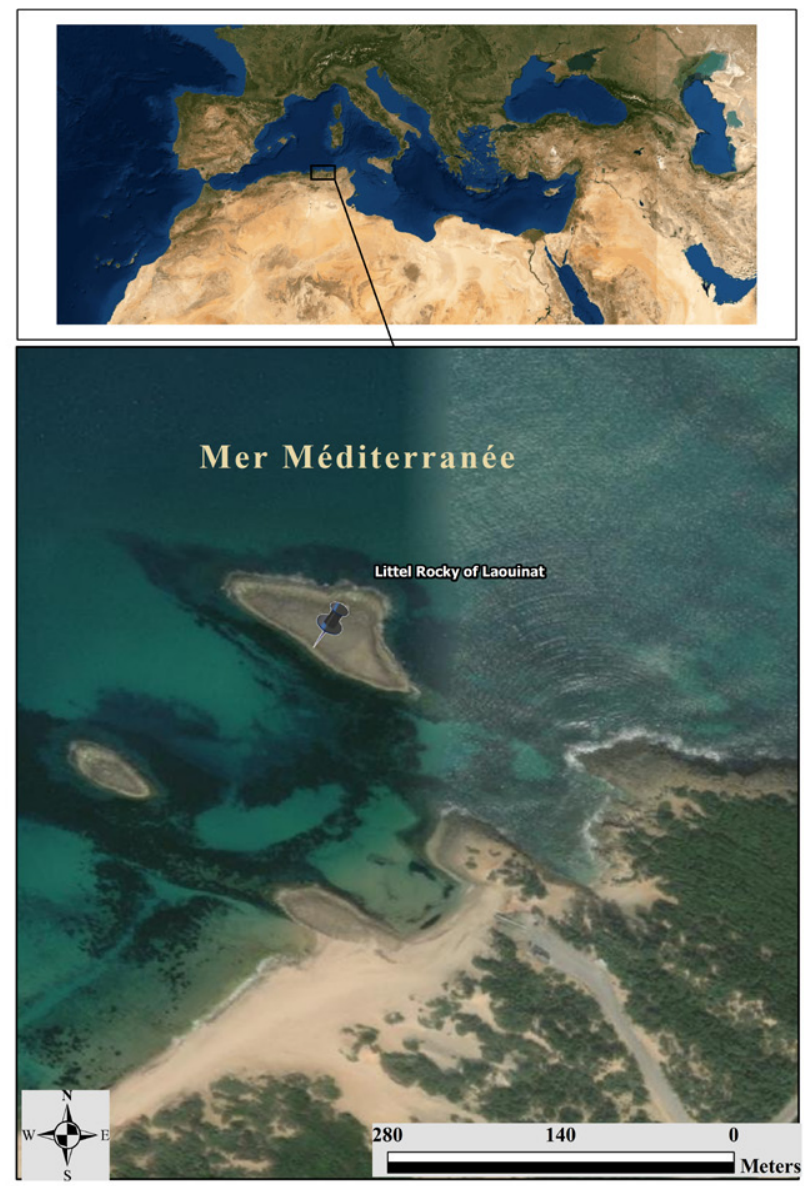

Fig. 1. Map showing the location of the little rocky of Laouinet wetland in northeast of Algeria.

This s land is constituted of sand stone dome, in the presence of cells dug in the eroded rock (Fig.1). The land dominates these a about $5 \mathrm{~m}$ maximum. The vegetation is rare, composed mostly of salicornia (Michelot, Laurent, 1992, 1993).

\section{Statistical analysis}

Prior to statistical analysis, we checked all the variables' normality (Kolmogorov-Smirnov test) and variance homogeneity (Levene's test). Variables, whose parametric tests cannot be applied, were log-transformed to meet the assumptions of the analysis.

Based on the observed number of pairs between 2004 to 2009 , the population growth rate was estimated for the whole study period as $\lambda=(\mathrm{N} \mathrm{t} / \mathrm{N} 0) 1 / \mathrm{t}$, where $\mathrm{N} 0$ is the initial population size, $\mathrm{N}$ the final population size and the number of years between the start and the end of the study period.

We performed the one-way ANOVA parametric test to determine whether there is a year effect (six-year of monitoring) on the different parameters (nests measurement, egg traits and incubation period); in the case of a significant effect, analysis will be complemented with LSD tests. We also used Pearson correlation to explore the relationships between egg breadth and egg volume, egg length and egg shape index, clutch size and egg measurement with latitude at different parts of the world. 


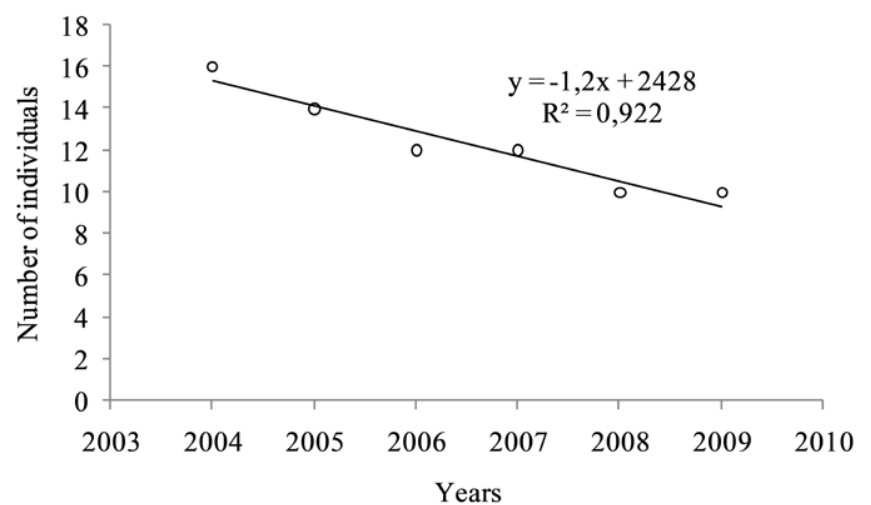

Fig. 2. Maximum abundance of Sterna hirundo between 2004 and 2009 at Laouinet small island, El Tarf, Algeria.

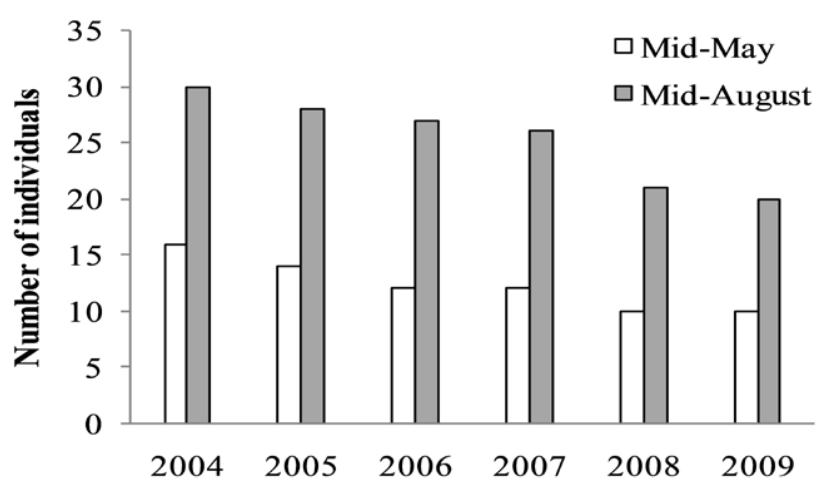

Fig. 3. Temporal patterns of the Common Tern population's establishment.

Table 1. Nest measurements.

\begin{tabular}{|c|c|c|c|c|}
\hline Nests characteristics & & Mean & Min. & Max. \\
\hline \multirow{2}{*}{$\begin{array}{l}\text { North africa } \\
(\mathrm{n}=37)\end{array}$} & internal diameter $(\mathrm{cm})$ & 11,78 & 8,5 & 13 \\
\hline & external diameter $(\mathrm{cm})$ & 17,61 & 11,6 & 24 \\
\hline \multirow{2}{*}{ Bocheński (1966) } & internal diameter $(\mathrm{cm})$ & 10 & 8 & 13 \\
\hline & external diameter $(\mathrm{cm})$ & 15 & 11.5 & 24 \\
\hline
\end{tabular}

A multivariate analysis of variance (MANOVA) with the GLM procedure was carried out by taking morphological parameters (egg volume, fresh mass, egg shape index) and hatching success as dependent variables and the six years of monitoring, the number of eggs by nests ( 2 vs. 3 egg) as independent variables (Wilk's lambda was the test criterion), in the case of a significant effect, analysis will be complemented with LSD tests. Significant effects were further explored by Kruskal-Wallis non-parametric test; this allowed us to evaluate the distribution of the clutch size according to the six years of monitoring. All statistical analyses were carried out using SPSS 17 (SPSS, Inc., Chicago, USA).

\section{Results}

\section{Population size}

In six seasons, we recorded 74 Common Terns individual at Laouinet small island, El-Tarf, Algeria. The greatest abundance of breeders have been observed at the first year of the study (2004), followed by a negative linear decrease until 2009 (Fig.2). The proportional change in population size during this period is a very worrisome $(\lambda=-0.62$ : Lambda is called the finite population growth rate) indicated an alarming population declining.

\section{Arrival and departure dates}

During these study years (six year of survey), mid-May was the period over which the first Common Tern individuals have occupied the place, the low number of the arrived individuals was recorded around mid-May $(12.33 \pm 2.33 \mathrm{SD})$. Then, the maximum Tern's population abundance was reached $(25.33 \pm 5.64 \mathrm{SD})$ after three months, by mid-August period in which all the birds leave the site (Fig. 3).

\section{Nest placement and measurement}

Almost all nests were located at the center of this small island with an average distance of $7.58 \mathrm{~m}$ from the island edge. Nests were mainly made with dead vegetation (stems and leaves) that had washed onshore, shell fragments, bones, stones, and sometimes plastic (Fig. 4). During the six years of the study, nests have been made uniformly, with a mean external diameter of (17.61 \pm 2.26 $\mathrm{SD})$, and a mean internal diameter of (11.78 $\pm 1.07 \mathrm{SD})$. So, no significant variation among nests' measurements have been detected (external diameter: Anova; $\mathrm{F}=1.562 ; \mathrm{df}=5 ; \mathrm{P}=0.200$, internal diameter: Anova; $\mathrm{F}=1.327 ; \mathrm{ddl}=5 ; \mathrm{P}=0.279$ ) (Table 1 ).

\section{Nesting facts}

The monitoring of 87 eggs from 37 nests during six breeding seasons enables us to obtain an interesting description of the Common Tern nesting facts (Table 2). Three eggs by nest have been counted for more than half of all the surveyed nests (54\%), two eggs for $38 \%$, and one egg for the rest of nests $(8 \%)$. The aforementioned clutch sizes have not been varied significantly $\left(\mathrm{X}^{2}=5.044, \mathrm{P}=0.88\right)$ across years (Fig. 4) (Table 2). Egg length ranged from $40 \mathrm{~mm}$ to $43.6 \mathrm{~mm}$, egg width from 29 to $31.6 \mathrm{~mm}$, and egg weight from 19 to 21 grams, All mean egg traits did not differ between the six years of monitoring (egg weight Anova; $\mathrm{F}$ $=3.224 ; \mathrm{df}=6 ; \mathrm{P}=0.010$ and egg length Anova; $\mathrm{F}=1.77 ; \mathrm{df}=5$; $\mathrm{P}=0.128$ ), only egg breadth (Anova; $\mathrm{F}=2.53 ; \mathrm{df}=5 ; \mathrm{p}=0.035$ ) increased with time and showed its maximum during the last 
Table 2. Nesting facts summary (87 eggs from 37 nests).

\begin{tabular}{|l|l|}
\hline Clutch size & 1-3Eggs \\
\hline Egg traits & \\
\hline Egg lenth & $40-43.6 \mathrm{~mm}$ \\
\hline Egg breadth & $29-31.6 \mathrm{~mm}$ \\
\hline Egg weight & $19-21$ grams \\
\hline Morphological Parameters & \\
\hline Egg volume & $17.85-20.4 \mathrm{~cm}^{3}$ \\
\hline Egg mass & $19-22$ grams \\
\hline Egg shape index & $0.68-0.76$ \\
\hline Incubation Period & $22-31$ day \\
\hline
\end{tabular}

year of the study (2009 to $2008 \mathrm{LSD}=0.20, \mathrm{P}=0.391,2009$ to $2007 \mathrm{LSD}=0.47, \mathrm{P}=0.04 ; 2009$ to $2006 \mathrm{LSD}=0.54, \mathrm{P}=0.02$, 2009 to $2005 \mathrm{LSD}=0.63, \mathrm{P}=0.00,2009$ to $2004 \mathrm{LSD}=0.58, \mathrm{P}=$ 0.00) (Fig. 5).

Concerning the morphological parameters, the egg volume array from 17.85 to $20.0 \mathrm{~cm}^{3}$, egg mass from 19 to 22 grams, and finally, the egg shape index varied between $0.68-0.76$. Over the six years, the morphological parameters (volume, mass, shape index) varied between the six years of the study (MANOVA: Wilks' $\lambda=0.762, \mathrm{~F}=1.312 ; \mathrm{P}=0.049)$, but does not vary with eggs number (MANOVA: Wilks' $\lambda=0.980, \mathrm{~F}=0.473$; $\mathrm{P}=$ 0.702 ), and their interaction (MANOVA: Wilks' $\lambda=0.839, \mathrm{~F}=$ $0.833 ; \mathrm{P}=0.640)$.

The egg volume varied between the years $(\mathrm{GLM} \mathrm{df}=5, \mathrm{~F}=$ $1.87 ; \mathrm{P}=0.030)$ was more important year after year $(2009$ to 2008 $\mathrm{LSD}=0.22, \mathrm{P}=0.49 ; 2009$ to $2007 \mathrm{LSD}=0.92, \mathrm{P}=0.00 ; 2009$ to $2006 \mathrm{LSD}=0.69, \mathrm{P}=0.03 ; 2009$ to $2005 \mathrm{LSD}=0.31, \mathrm{P}=0.01$; 2009 to $2004 \mathrm{LSD}=0.31, \mathrm{P}=0.00$ ) (Fig.6) but does not vary with the number of eggs and their interaction $(\mathrm{GLM} \mathrm{df}=1, \mathrm{~F}=0.663$; $\mathrm{P}=0.418$, GLM df $=5, \mathrm{~F}=1.099 ; \mathrm{P}=0.369$ ).

The egg shape index does not vary from year to year, neither with the number of eggor their interaction $(\mathrm{GLM} \mathrm{df}=5, \mathrm{~F}=1.75$, $\mathrm{P}=0.134 ; \mathrm{GLM} \mathrm{df}=1, \mathrm{~F}=0.613, \mathrm{P}=0.436 ; \mathrm{GLM} \mathrm{df}=5 \mathrm{~F}=1.16$, $\mathrm{P}=0.335$ ).

The egg mass also does not vary in years or the number of eggs and their interaction ( $\mathrm{GLM} d f=5, \mathrm{~F}=0.578, \mathrm{P}=0.717$; $\mathrm{GLM} \mathrm{df}=1, \mathrm{~F}=0.421, \mathrm{P}=0.519 ; \mathrm{GLM} \mathrm{df}=5, \mathrm{~F}=0.600, \mathrm{P}=$ $0.700)$. The egg volume depended more on the egg breath $(\mathrm{r}=$ $0.753, \mathrm{P}=0.03)$; however, the egg shape depended negatively on the egg length $(\mathrm{r}=-0.645, \mathrm{P}=0.028)$.

The mean incubation period of Common Tern is $25.5( \pm 3.4$.) and varies betweenthe range of 22 to 31 days. The incubation period varies between the six year of monitoring (Anova; $\mathrm{F}=31.28$; $\mathrm{df}=5 ; \mathrm{P}=0.00)$ and showed an increase from year to year $(2009$ to $2008 \mathrm{LSD}=0.91, \mathrm{P}=0.25,2009$ to $2007 \mathrm{LSD}=0.87, \mathrm{P}=0.01$; 2009 to $2006 \mathrm{LSD}=0.87, \mathrm{P}=0.00 ; 2009$ to $2005 \mathrm{LSD}=0.83, \mathrm{P}=$ $0.00 ; 2009$ to $2004 \mathrm{LSD}=0.81, \mathrm{P}=0.00$ ) (Fig.7).

\section{Breeding success}

The hatching success was $70.5 \%$ in $2004,68.75 \%$ in $2005,71.42 \%$ in $2006,71.42 \%$ in $2007,69.23 \%$ in 2008 and $69.23 \%$ in 2009 . The hatching success does not vary between years, eggs' number and their interaction $(\mathrm{GLM} \mathrm{df}=5, \mathrm{~F}=0.963, \mathrm{P}=0.337$; $\mathrm{GLM} \mathrm{df}=5$,

\section{Clutch size}

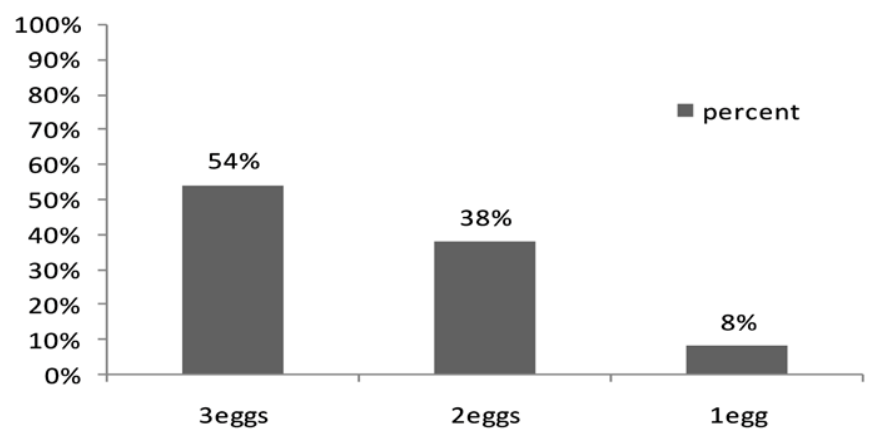

Fig. 4. Clutch size variation.

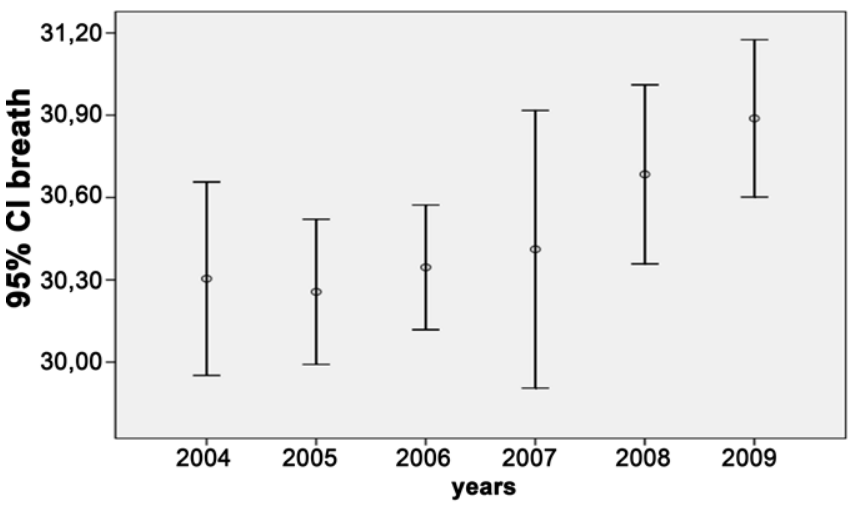

Fig. 5.Yearly eggs breadth variation.

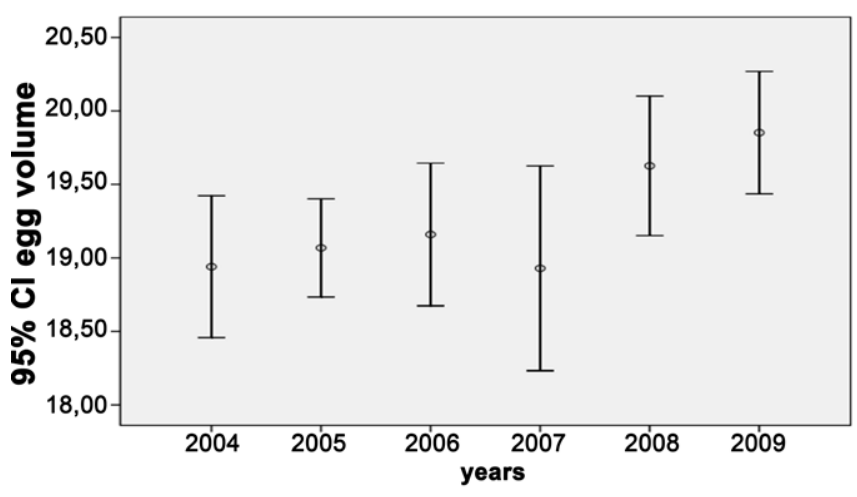

Fig. 6. Yearly egg volume trend.

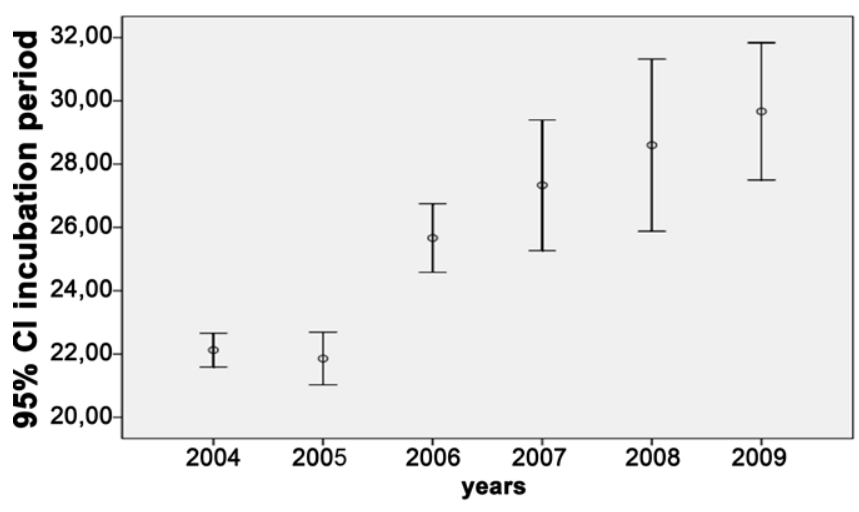

Fig. 7. Yearly variation of the Common Tern incubation period. 
Table 3. International egg measurements variation.

\begin{tabular}{|l|c|c|c|c|l|}
\hline Country & Egg length & Egg breadth & Egg volume & Egg shape & Author \\
\hline Present study & $41.8 \mathrm{~mm}$ & $30.3 \mathrm{~mm}$ & $19.12 \mathrm{~cm}^{3}$ & 0.72 & \\
\hline Switzerland & $41.8 \mathrm{~mm}$ & $30.4 \mathrm{~mm}$ & $20.22 \mathrm{~cm}^{3}$ & - & (Noll, 1943) \\
\hline Germany, Oberrhein & $41.84 \mathrm{~mm}$ & $30.56 \mathrm{~mm}$ & $20.46 \mathrm{~cm}^{3}$ & - & Glutz von Blotzheim, Bauer, 1982 \\
\hline Slovakia & $41.9 \mathrm{~mm}$ & $30.3 \mathrm{~mm}$ & $20.14 \mathrm{~cm}^{3}$ & - & Glutz von Blotzheim, Bauer, 1982 \\
\hline Austria & $41.03 \mathrm{~mm}$ & $30.2 \mathrm{~mm}$ & $19.59 \mathrm{~cm} 3$ & - & Glutz von Blotzheim, Bauer, 1982 \\
\hline Bulgaria & $41.4 \mathrm{~mm}$ & $30.4 \mathrm{~mm}$ & $20.03 \mathrm{~cm} 3$ & - & (Konigstedt et al., 1991) \\
\hline Poland & $41.5 \mathrm{~mm}$ & $30.6 \mathrm{~mm}$ & $20.43 \mathrm{~cm} 3$ & - & (Becker et al., 1997) \\
\hline Germany, Wadden Sea & $41.8 \mathrm{~mm}$ & $30.3 \mathrm{~mm}$ & $20.09 \mathrm{~cm} 3$ & - & (Becker et al., 1997) \\
\hline Netherlands & - & - & $19.72 \mathrm{~cm} 3$ & - & (Brenninkmeijer et al., 1997) \\
\hline Slovenia & $41.23 \mathrm{~mm}$ & $30.07 \mathrm{~mm}$ & $19.52 \mathrm{~cm} 3$ & 0.73 & (Vorgin, 1998) \\
\hline Romania & $41.28 \mathrm{~mm}$ & $31.02 \mathrm{~mm}$ & - & - & (Shurulinkov et al, 2016) \\
\hline
\end{tabular}

$\mathrm{F}=0.145, \mathrm{P}=0.980 ; \mathrm{GLM} d \mathrm{df}=5, \mathrm{~F}=0.855, \mathrm{P}=0.526)$. Our results showed a stabilized hatching success and a best estimation of breeding success.

\section{Discussion}

In the object to develop conservation prescriptions of the unique population of Common Tern in the Mediterranean North West, we aimed to investigate the breeding biology and habitat of the majority of Common Tern in winters on the western seaboard of Africa, principally west and south Africa; while the minority appear to winter off Portugal (Muselet, 1982; Becker, Ludwigs, 2004), in Central Europe, the Common Tern starts breeding in May (Glutz von Blotzheim, Bauer, 1982). Yésou et al. (2005) recorded the presence of the Common Tern in Europe during the breeding period (mid-May to mid-August), which is consistent with our results. We also reported its presence in the study area during the same period in the breeding season; the Common Tern occupied several types of habitat, such us, roofs used by several hundreds of nesting pairs in Netherlands and Latvia (Stienen, 2002; Strazds, 2002), artificial sites such as gravel pits, peat pits, bog ponds, patches of dumped soil from dredging, small concrete structures in freshwater lakes, fish farms, or other artificial islands, and in particular, rafts in Switzerland, also salt marshes, and sandy or gravel sites in the US coastal sites (Greenhalgh, Greenwood, 1975; Priednieks, Viksne, 1989; Fasola, 1993; Fasola, Canova, 1996; Leibak et al., 1994; Becker, Sudmann, 1998; Beaud, 2001; Sudmann et al., 2003). Our results are overall consistent with those of the previous studies (Hakala, Jokinen, 1971; Axell, Hosking, 1977; Skinner, 1998) in which the Common Tern also occupy rocky or stony islands during the breeding period.

We recorded a marked decline in the Common Tern population $(\lambda=-0.60 \pm 0.087)$ over the period of our study, this phenomenon was also observed in many regions in the word (Europe, USA, etc.) and was debated by many authors (Scarton, 2010; Erwin et al., 2011; Morris et al., 2012; Szostek, Becker, 2012; Nisbet et al., 2013). The decline of Common Tern population over time can be caused by several factors such as: sea level rise (Scarton, 2010), flooding that leads to decreased productivity in Common Terns (Becker, Anlauf, 1988; Palestis, 2009) and the combination of increased emigration and decreased recruit- ment (Erwin et al., 2011; Szostek, Becker, 2012). In Algeria, in the month of May, the Common Tern individual breeders are present in small numbers. These findings are translated into a low recruitment rate. However, in the month of August, the recruitment rate increases with the birth of the Common Tern chicks, which indicates a high emigration rate. We think that the main cause of the decline of the unique population of Common Tern is the decreased recruitment. The Common Tern may move to a new site because of predation or other reasons for breeding failure (McNicholl, 1975; Gochfeld, 1979).

According to Shurulinkov et al. (2016), four types of Common Tern nests were recorded in Romania based on their different constitutions; nests built by mussel shells, nests formed as a small inundation in the sand without any building material, nests hidden in the vegetation or among and other objects like stones or pieces of timber, and nests built by wooden sticks and straws. In our study, the building material used in the Common Tern nests was mainly mussel shells Sandpit, stems and leaves as reported in Romania. The Common Tern nests' measurements in our study revealed a mean external diameter of $17.61 \pm 2.26 \mathrm{~cm}$ (varying between 11.60 and $24 \mathrm{~cm}$ ) and a mean internal diameter of $11.78 \pm 1.07 \mathrm{~cm}$ (varying between 8.5 and $13 \mathrm{~cm}$ ); our results are similar to those recorded by Bocheński (1966).

Many studies have shown that there is a little variation in Clutch size between Charadrii formes species, but a lot of them marked a constant clutch size of 4 eggs (Lack, 1968; Maclean, 1972; Arnold, 1999; Adamou et al., 2009). Becker, Ludwigs (2004) stated that the Common Tern laid usually 2-3 eggs, occasionally 1 or 4 eggs and very rarely $>4$. The average clutch size in our study area $(2.45 \pm 0.65)$ is similar to those reported in many studies conducted over the Common Tern breeding range, as Tunisia (2.46; Chokri et al., 2010), Romania (2.44; Shurulinkov et al., 2016), Orkney and Shetland (2.55; Bullock, Gomersall, 1981), NE Slovenia (2.55; Janžekovič et al., 2003 and 2.69; Vogrin, 1998), England (2.65; Langham, 1972), France (2.7; Yésou et al., 2005), USA (2.76; Nisbet, Welton, 1984), Germany (2.84; Witt, 1970) and Russia (2.88; Borodulina, 1960). The Common Tern clutch size is influenced by many factors: parental age (Hays, 1978; Nisbet et al., 1984), laying date (Nisbet, Welton, 1984; Becker, 1996), habitat and site (Nisbet, Drury, 1972; Safina et al., 1989), year (Frick, Becker, 1995), and weath- 
er (Becker, 1985). However, the clutch size does not vary with latitude (correlation between clutch size and latitude in different parts of the world, $\mathrm{r}=0.46, \mathrm{p}=0.208$ ) (Table3).

Egg size is an important life-history parameter, may either reflect female characteristics and/or environmental conditions, and influences survival and reproductive success (Thomas, 1983; Stokland, Amundsen, 1988; Williams, 1994; Rutkowska, Cichon, 2005). The investment in egg size is thought to represent a strong mechanism through which maternal effects can influence components of offspring fitness. Within several avian species and races, egg size varies significantly and is often positively correlated with hatchling phenotype, growth and survival (Vaisanen, 1969; Makatsch, 1974). Mean egg length, breadth and volume in the Algerian population of Common Tern is within the range of those characteristics known for a few other populations of this species, in different parts of Europe (Table 3).

It seems that the Common Tern egg size does not change with latitude and longitude, in Europe (Vogrin, 1998) and in North Africa (based on our results);also, it does not vary with latitude $(r=0.32, p=0.135)$. However, our study shows that the Common Tern egg size (egg volume and breadth) varied between years and increased over the six years of monitoring, but does not vary according to the number of eggs per nest. Our results confirmed those suggested by Lack (1947). Brenninkmeijer et al. (1997) and Nisbet (1997) supposed that food availability and calcium resources have an effect on Common Tern egg size. Fasola, Bogliani (1990) recorded that the foraging distribution of Common Terns depended on the location of their preferred habitats, which were available only at given distances from the colonies. The colony was observed in neighboring El Mellah lagoon (Telailia et al., 2017); this lagoon has been referred by Chaoui et al. (2006) with a very important diversity, richness and abundance of ichtyofauna.

We recorded a mean incubation period of $25.5 \pm 3.4$ days ranging from 22 to 31 days. The incubation period in our population varied and increased from year to year. Many authors showed that the mean incubation periods increase from 24 to 31.5 days, however, the individual egg's hatching takes place af ter 33 days (Nisbet, Cohen, 1975; Nisbet, Welton, 1984; Wendeln, Becker, 2000). The increasing or the decreasing of the incubation period depended on egg temperature maintained within the bird-nest incubation unit (Ar, Sidis, 2002; Deeming, 2002; Turner, 2002) and the nest predation (Becker, Ludwigs, 2004), that becomes locally a limiting factor due to the reduction of colonies and concentration numbers. Several opportunistic native species sometimes have serious impacts on colonies (Yésou et al., 2005). In our study area, the presence of (Larus michahellis) (pers observation by Salah Telailia) Common Tern predator in the nesting site may explain the increasein the incubation period.

Our results showed a stabilized hatching success ranging from 69.23 to $71.42 \%$, our approach with Langham (1972), where no adverse factors exist, hatching success may reach typically over 90\%. Becker (1998) has studied 5 Common Terns' colonies over 17 years in Wadden Sea, Germany, and recorded a hatching success of $87 \%$, Witt (1970) in south-west Germany, recorded a hatching success of $77 \%$. However, in Finland, the hatching success recorded by Lemmetyinen (1973) was $80 \%$.

\section{Conclusion}

This study provides the first traits of population dynamics and breeding biology of Common Tern in North Africa, and highlighted the alarming population decline. For a better understanding of life history, protection and conservation patterns of Sterna hirundo, this work needs to be deepened and extended to define various important parameters of bio-ecology of this migratory sea bird in its North African breeding habitat such as: habitat selection and management, nest site selection, diet, and so on.

\section{References}

Adamou, A.E., Kouidri, M., Chabi, Y., Skwarska, J. \& Bańbura J. (2009). Egg size variation and breeding characteristics of the Black-Winged Stilt Himantopus himantopus in a Saharan Oasis. Acta Ornithol., 44(1), 1-7. DOI: 10.3161/000164509X464821.

Ar, A. \& Sidis Y. (2002). Nest microclimate during incubation. In D.C. Deeming (Ed.), Avian incubation: behaviour, environment, and evolution (pp 143-160). Oxford: Oxford University Press.

Arnold, T.W. (1999). What limits clutch size in waders? J. Avian Biol., 30(2), 216-220. DOI: $10.2307 / 3677131$

Axell, H.E. \& Hosking E. (1977). Minsmere: Portrait of a bird reserve. London: Hutchinson.

Baaloudj, A., Bouzid, A., Nedjah, R., Samraoui, F. \& Samraoui B. (2018). Distribution and breeding of the Slender-billed Gull Chroicocephalus genei, Common Tern Sterna hirundo and Little Tern Sternula albifrons in Algeria. Revue d'Ecologie (Terre et Vie), 73(3), 385-395. http://hdl.handle.net/2042/68149.

Baccetti, N., Capizzi, D., Corbi, F., Massa, B., Nissardi, S., Spano, G. \& Sposimo P. (2009). Breeding shearwaters on Italian islands: population size, island selection and co-existence with their main alien predator, the black rat. Rivista Italiana di Ornitologia, 78(2), 83-100.

Beaud, M. (2001). Quelques expériences dans le domaine de la protection de la Sterne Pierregarin Sterna hirundo en période de nidification. Actes du 39e colloque interrégional d'ornithologie, Yverdon-les-Bains (Suisse), 1999. Nos Oiseaux, Suppl. 5, 73-80.

Becker, P.H. (1985). Common Tern breeding success and nesting ecology under predation pressure of Herring Gulls. In V.D. Ilyichev \& V.M. Gavrilov (Eds.), Proceedings of the XVIII International Ornithological Congress (pp. 1198-1205). Nauka, Moscow.

Becker, P.H. \& Anlauf A. (1988). Nistplatzwahl und Bruterfolg der Flußseeschwalbe (Sterna hirundo) im Deichvorland. I. Nestdichte. Ökologische Vögel, 10, 27-44.

Becker, P.H. (1996). Flußseeschwalben (Sterna hirundo) in Wilhelmshaven. Oldenburger Jahrbuch, 96, 263-296.

Becker, P.H., Frank, D. \& Wagener M. (1997).Luxury in freshwaterand stress at sea? The foraging of the Common Tern Sterna hirundo. Ibis, 139(2), 264-269. DOI: 10.1111/j.1474-919X.1997.tb04624.

Becker, P.H. (1998). Langzeittrends des Bruterfolgs der Flußseeschwalbeundseiner EinflußgrößenimWattenmeer. Vogelwelt, 119, 223-234.

Becker, P.H. \& Sudmann S.R. (1998).Quo vadis Sterna hirundo? Schlußfolgerungenfür den Schutz der Flussseeschwalbe. Vogelwelt, 119, 293-304.

Becker, P.H. \& Ludwigs J.-D. (2004). Sterna hirundo Common Tern. Birds of the Western Palearctic Update, 6(1-2), 91-137.

Belopol'skii, L.O. (1957). Ecology of sea colony birds of the Barents Sea. Moscow, Leningrad: Izdatel'stvo Akad. Nauk SSSR.

Blondel, J. \& Aronson J. (1999). Biology and wildlife of the Mediterranean region. New York: Oxford University Press.

Bocheński, Z. (1966). Nesting of Common and Black Terns. Acta Zool. Cracov., 11, 423-449.

Borodulina, T.L. (1960). Biology and economic importance of gulls and terns of Southern-USSR water bodies. In Proceedings of the Institution of Animal Morphology of the Academy for Sciences USSR.

Brenninkmeijer, A., Klaassen, M. \& Stienen W.M. (1997). Sandwich Terns Sterna sandvicensis feeding on shell fractions. Ibis, 139(2), 397-400. DOI: 10.1111/j.1474-919X.1997.tb04641.x. 
Bullock, I.D. \& Gomersall C.H. (1981). The breeding populations of Terns in Orkney and Shetland in 1980. Bird Study, 28, 187-200. DOI $10.1080 / 00063658109476723$.

Chaoui, L., Kara, M.H., Faure, E. \& Quignard J-P. (2006). Lichtyofaune de la lagune du Mellah (Algérie Nord-Est): diversité, production et analyse des captures commerciales. Cybium, 30(2), 123-132.

Chokri, M.A.,Selmi, S., Sadoul, N. \& Béchet A. (2010). Nidification des sternes naines Sterna albifrons, Pierregarin Sterna hirundo et Hansel, Sterna nilotica dans le Salin de Sfax, Tunisie: Chronologie, effectifs et succès reproducteur. Alauda, 78(1), 51-60.

Croxall, J.P. \& Prince P.A. (1980). Food, feeding ecology and ecological segregation of seabirds at South Georgia. Biol. J. Linn. Soc., 14(1), 103-131. DOI: 10.1111/j.1095-8312.1980.tb00101.x.

Croxall, J.P., Butchart, S.H.M., Lascelles, B., Stattersfield, A.J., Sullivan, B. Symes, A. \& Taylor P. (2012). Seabird conservation status, threats and priority actions: a global assessment. Bird Conserv. Int., 22, 1-34. DOI: $10.1017 /$ S0959270912000020.

Deeming, D.C. (2002). Importance and evolution of incubation in avian reproduction. In D.C. Deeming (Ed.), Avian incubation: behaviour, environment, and evolution (pp. 1-7). Oxford: Oxford University Press.

Defos du Rau, P., Bourgeois, K., Ruffino, L., Dromzée, S., Ouni, R., Abiadh, A., Estève, R., Durand, J-P., Anselme, L., Faggio, G., Yahya, J.M., Peters, P., Rguibi, H., Renda, M., Miladi, B., Hamrouni, H., Alilech, S., Ben Dhafer, A., Nefla, A., Jaouadi, W., Agrebi, S. \& Renou S. (2012). New assessment of the world's largest colony of Scopoli's Shearwater Calonectris diomedea. In P. Yésou, N. Baccetti \& J. Sultana (Eds.), Ecology and conservation of Mediterranean Sea birds and other bird species under the Barcelona Convention (pp. 26-28). Proceedings of the 13th Medmaravis Pan-Mediterranean Symposium. Alghero (Sardinia) 14-17 Oct. 2011. Medmaravis, Alghero.

Del Hoyo, J., Elliot, A \& Sargatal J. (Eds.) (1994). Handbook of the birds of the World. Vol.2. New World Vultures to Guineafowl. Barcelona: Lynx Edicions.

Del Hoyo, J., Elliott, A. \& Sargatal J. (1996). Handbook of the birds of the world. Vol. 3. Hoatzinto Auks. Barcelona: Lynx Edicions.

Diamond, A.W. \& Devlin C.M. (2003). Seabirds as indicators of changes in marine ecosystems: ecological monitoring on Machias Seal Island. Environ. Monit. Assess., 88(1-3), 153-175. DOI: 10.1023/A:1025560805788.

Erwin, R.M., Brinker, D.F., Watts, B.D., Costanzo, G.R. \& Morton D.D. (2011). Islands at bay: rising seas, eroding islands, and waterbird habitat loss in Chesapeake Bay (USA). J. Coast. Conserv.,15(1), 51-60. DOI: $10.1007 /$ s11852-010-0119-y.

Fasola, M.\& Bogliani G. (1990). Foraging ranges of an assemblage of mediterranean seabirds. Colonial Waterbirds, 13(1), 72-74. DOI $10.2307 / 1521424$.

Fasola, M. (1993). Distribution, population and habitat requirements of the Common Tern (Sterna hirundo) and the Little Tern (Sterna albifrons) breeding in the Mediterranean. In J.S. Aguilar, X. Monbailliu \& A.M Paterson (Eds.), Estatus y Conservación de Aves Marinas (pp. 97-106) Madrid: Sociedad Española de Ornitología.

Fasola, M. \& Canova L. (1996). Conservation of Gull and Tern Colony Sites in Northeastern Italy, an Internationally Important Bird Area. Colonial Waterbirds, 19(Special Publication 1), 59-67. DOI $10.2307 / 1521946$.

Frick, S. \& Becker P.H. (1995). Unterschiedliche Ernährungsstrategien von Fluß-und Küstenseeschwalbe (Sterna hirundo und S. paradisaea) im Wattenmeer. J. Ornithol., 136, 47-63.

Glutz von Blotzheim, U.N. \& Bauer K.M. (1982). Handbuch der Vögel Mitteleuropas, 8 (II). Akad. Verlagsges.,Wiesbaden Nationaal Natuurhistorisch Museum Naturalis, KNNV Uitgeverij \& European Invertebrate Survey-Nederland, Leiden.

Gochfeld, M. (1979). Group adherence in emigration of Common Terns. Bird-Banding, 50, 365-366.

Greenhalgh, M.E. \& Greenwood M.J. (1975). Foods of an estuarine Common Tern colony. Naturalist, 935, 145-146.

Hakala, T. \& Jokinen M. (1971). Pesivä kalatiirapopulaatio tehdashallin katola. Ornis Fenn., 48, 135-137.

Hays, H. (1978). Timing and breeding success in three- to seven-year- old Common Terns. Ibis, 120, 127-128.

Hoyt, D.F. (1979). Practical methods of estimating volume and fresh weight of bird eggs. The Auk, 96(1), 73-77. DOI: 10.1093/auk/96.1.73.
Hunt, G.L., Eppley, Z., Burgeson, B. \& Squibb R. (1981). Reproductive ecology, foods and foraging areas of seabirds nesting on the Pribilof Islands, 1975-1979. Environmental assessment of the Alaskan Continental Shelf.Final reports of principal investigators. Boulder Colorado, National Oceanic Atmospheric Administration, Office of Marine Pollution Assessment, Juneau, Alaska. Biological Studies, 12, 1-258.

International union for conservation of nature, Red listwww.uicn.org, consulted April 2018

Janžekovič, F., Štumberger, B. \& Denac D. (2003). Common Tern’s Sterna hirundo clutch size, egg dimensions and phenology of its arrival to the breeding site in NE Slovenia. Acrocephalus, 24(117), 61-66.

Kildaw, S.D., Irons, D.B., Nysewander, D.R. \& Buck C.L. (2005). Formation and growth of new seabird colonies: the significance of habitat quality. Mar. Ornithol., 33, 49-58.

Konigstedt, D.G.W., Robel, D. \& Gottschalk W. (1991). Brutbiologishe, okologishe und faunistische UntersuchungenzueinigenVogelarten der Salinen von Burgas (Bulgarien). Zool. lb. Syst., 118, 117-146.

Lack, D. (1947). The significance of clutch size.I- II. Ibis, 89(2), 302-352. DOI: 10.1111/j.1474-919X.1947.tb04155.x.

Lack, D. (1968). Ecological adaptations for breeding in birds. London: Methuen. Langham, N.P.E. (1972). Chick survival in Terns Sterna spp. With particular reference to the Common Tern. J. Anim. Ecol., 41, 385-395.

Leibak, E., Lilleleht, V. \& Veromann H. (1994). Birds of Estonia. Status distribution and numbers. Tallinn: Estonian Academy Publishers.

Lemmetyinen, R. (1973). Feeding ecology of Sterna paradisaea Pontopp. and S.hirundo L. in the archipelago of southwestern Finland. Ann. Zool. Fenn., 10(4), 507-525.

LoValvo, F. \& Massa B. (2000). Some aspects of the population structure of Storm Petrels Hydrobates pelagicus breeding on a Mediterranean island. Ringing \& Migration, 20(2), 125-128. DOI: 10.1080/03078698.2000.9674233

Maclean, G.L. (1972). Clutch size and evolution in Charadrii. The Auk, 89, 299-324. DOI: $10.2307 / 4084208$.

Makatsch, W. (1974). Die Eier der Vogel Europas. Vol. 1. Radebeul: Neumann Verlag.

Martínez-Abraín, A. (2003). Research applied to the conservation of seabird breeding on Islands of the Western Mediterranean. PhD Thesis, Universitat de Barcelona.

McNicholl, M.K. (1975). Larid site tenacity and group adherence in relation to habitat. The Auk, 92(1), 98-104. DOI: $10.2307 / 4084420$.

Michelot, J.L. \& Laurent L. (1992). Sternes en Algérie. Alauda, 60, 114-115.

Michelot, J.L. \& Laurent L. (1993). Observations estivales doiseaux marins sur les plages algériennes et marocaines. Le Bièvre, 13, 109-117.

Monbailliu, X. (Ed.) (2013). Mediterranean marine avifauna: population studies and conservation (Vol. 12). Springer Science \& Business Media.

Morris, R.D., Pekarik, C. \& Moore D.J. (2012). Current status and abundance trends of Common Terns breeding at known coastal and inland nesting regions in Canada. Waterbirds, 35(2), 194-207.DOI: 10.1675/063.035.0202.

Muselet, D. (1982). Les quartiers d'hivernage des Sternes pierregarins (Sterna hirundo) européennes. L'Oiseau et R.F.O., 52, 219-235.

Nisbet, I.T.C. \& Drury W.H. (1972).Measuring breeding success in Common and Roseate Terns. Bird-Banding, 43, 97-106. DOI: 10.2307/4511853.

Nisbet, I.C.T. \& Cohen M.E. (1975). Asynchronous hatching in Common and Roseate Terns Sterna hirundo and S. dougallii. Ibis, 117, 374-379. DOI: 10.1111/j.1474-919X.1975.tb04225.x.

Nisbet, I.C.T. \& Welton M.J. (1984). Seasonal variations in breeding success of Common terns: consequences of predation. The Condor, 86(1), 53-60. DOI: $10.2307 / 1367345$.

Nisbet, I.C.T., Winchell, J.M. \& Heise A.E. (1984). Influence of age on the breeding biology of Common terns. Colonial Waterbirds, 7, 117-126. DOI: $10.2307 / 1521090$.

Nisbet, I.T.C. (1997). Female Common terns Sterna hirundo eating mollusc shells: evidence for calcium deficits during egg laying. Ibis, 139(2), 400-401. DOI: 10.1111/j.1474-919X.1997.tb04642.x.

Nisbet, I.C.T., Veit, R.R., Auer, S.A. \&. White T.P. (2013). Marine birds of the Eastern United States and the Bay of Fundy: distribution, numbers, trends, threats, and management. Nuttall Ornithological Monographs, No. 29. Cambridge: Nuttall Ornithological Club.

Nisbet, I.C.T., Arnold, J.M., Oswald, S.A., Pyle, P. \& Patten M.A. (2017). Common tern (Sterna hirundo), version 3.0. In P.G. Rodewald (Ed.), The birds of North America. Ithaca: Cornell Lab of Ornithology. DOI: 10.2173/ bna.comter.03. 
Noll, H. (1943). Die Flussseeschwaibe am Untersee. Ornithologisher Beobachter, 40, 101-109.

Page, D.A. (2014). Use of Coastal Islands by Seabirds: A tool to guide future Marine Protected Areas in California. Master's Projects and Capstones.

Palestis, B.G. (2009). Use of artificial eelgrass mats by saltmarsh-nesting Common terns (Sterna hirundo). In Vivo, 30(3), 11-16.

Panda, P.C. (1996). Shape and texture. In Textbook on egg and poultry technology. New Delhi, India.

Pearson, T.H. (1968). The feeding biology of sea-bird species breeding on the FarneIslands, Northumberland. J. Anim. Ecol., 37(3), 521-552. DOI $10.2307 / 3073$.

Priednieks, J. \& Viksne J. (1989). Latvijas ligzdojošo putnu atlants, 1980-1984. Zinātne, Latviešuval.

Rutkowska, J. \& Cichon M. (2005). Egg size, offspring sex and hatching asynchrony in zebra finchesTaeniopygia guttata. J. Avian Biol., 36(1), 12-17. DOI: $10.1111 / \mathrm{j} .0908-8857.2005 .03469 . x$.

Safina, C., Witting, D. \& Smith K. (1989). Viability of salt marshes as nesting habitat for Common terns in New York. The Condor, 91(3), 571-584. DOI: $10.2307 / 1368107$.

Scarton, F. (2010). Long term decline of a Common tern (Sterna hirundo) population nesting in Salt Marshes in Venice Lagoon, Italy. Wetlands, 30(6), 1153-1159. DOI: 10.1007/s13157-010-0106-y.

Shurulinkov, P., Daskalova, G., Michov, S. \& Koev V. (2016). The distribution, numbers, and breeding of terns and waders on the sand islands along the Bulgarian-Romanian section of the Danube. North-Western Journal of Zoology, 12(1), 65-77.

Skinner, N. (1998). Common terns nesting on roofs in Suffolk. British Birds, $91,140-141$.

Snow, D.W. \& Perrins C.M. (1998). The birds of the Western Palearctic: concise edition.Vols 1-2. Oxford: Oxford University Press.

Stienen, E. (2002). Visdief Sterna hirundo. In Sovon Vogelonderzoek Nederland 2002. Atlas van de Nederlandse Broedvogels 1998-2000 (pp. 248-249). Nederlandse Fauna 5. Leiden: Nationaal Natuurhistorisch Museum Naturalis, KNNV Uitgeverij \& European Invertebrate SurveyNederland.

Stokland, J.N. \& Amundsen T. (1988). Initial size hierarchy in broods of the shag: Relative significance of egg size and hatching asynchrony. The Auk 105, 308-315. DOI:10.2307/4087495.

Strazds, M. (2002). Zīrini uz jumta. Fragmenti no kādastāsta. Putnidabā 11(3), 20-22.

Sudmann, S.R., Boschert, M. \& Zintl H. (2003). Hat die Flussseeschwalbe (Sterna hirundo) an Flüssen noch eine Überlebenschance? Charadrius, $39,48-57$.

Szostek, K.L. \& Becker P.H. (2012). Terns in trouble: demographic consequences of low breeding success and recruitment on a Common Tern population in the German Wadden Sea. Journal of Ornithology, 153(2), 313-326. DOI: 10.1007/s10336-011-0745-7.
Šúr, M., Bunbury, N. \& Crommenacker J.V.D. (2013). Frigatebirds on Aldabra Atoll: population census, recommended monitoring protocol and sustainable tourism guidelines. Bird Conserv. Int., 23(2), 214-220. DOI: $10.1017 /$ S0959270913000087.

Taibi, A., Ghermaoui, M. \& Oubaziz B. (2014). First study of the reproduction of Cory's shearwater Calonectris diomedea (Procellariidae, Aves) at the Rachgoun Island (BeniSaf, Algeria). Advances in Environmental Biology, 8(10), 15-20.

Telailia, S., Boutabia, L., Bensouilah, M.A, \& Houhamdi M. (2014). Breeding biology of Cory's Shearwater (Calonectris diomedea) in North East Algeria. International Journal of Current Science, 11, 120-127.

Telailia, S., Boutabia, L., Khemis, M.D.E, Elafri, A. \& Djebbari N. (2017) Multi-annual and Seasonal patterns of waterbird assemblages in a Mediterranean coastal lagoon (El Mellahlagoon) of Northeastern Algeria Ekológia (Bratislava), 36(2), 146-157. DOI: 10.1515/eko-2017-0013.

Thomas, C.S. (1983). The relationship between breeding experience, egg volume and reproductive success of the kittiwake Rissa tridactyla. Ibis, 125(4), 567-574. DOI: 10.1111/j.1474-919X.1983.tb03151.x.

Turner, J.S. (2002). Maintenance of egg temperature. In D.C. Deeming (Ed.), Avian incubation: behaviour, environment, and evolution (pp. 119-142). Oxford: Oxford University Press.

Vaisanen, R.A. (1969). Evolution of the Ringed plover (Charadrius luaticula L.) during the last hundred years in Europe. Ann. Acad. Sci. Fenn., 149, $1-90$.

Vogrin, M. (1998). Egg size of the Common tern Sterna hirundo in Slovenia. Ornis Svecica, 8, 87-90.

Weimerskirch, H., Inchausti, P., Guinet, C. \& Barbraud C. (2003). Trends in bird and seal populations as indicators of a system shift in the Southern Ocean. Antarct. Sci., 15(2), 249-256. DOI: 10.1017/S0954102003001202.

Wendeln, H. \& Becker P.H. (2000). Does disturbance by nocturnal predators affect bodymass of adult Common terns? Waterbirds, 22 (3): 401-410. DOI: $10.2307 / 1522116$.

Wetlands International (2006). Waterbird population estimates. Wageningen: Wetlands International.

Williams, T.D. (1994). Intraspecific variation in egg size and egg composition in birds: effects on offspring fitness. Biol. Rev. Camb. Philos. Soc., 68(1) $35-59$.

Witt, K. (1970). Bestandsentwicklung und daten zur brutbiologie der Flußseeschwalbe (Sterna hirundo) am Oberrhein. Vogelwelt, 91, 24-8.

Yésou, P., Bernard, F., Marquis, J. \& Nisser J. (2005). Biologie de reproduction de la sterne Pierregarin Sterna hirundo sur l'île de Béniguet, Finistère. Alauda, 73(2), 107-118. 